\title{
LARVICIDAL ACTIVITY OF BACILLUS THURINGIENSIS KURSTAKi Against TUta AbSOLUta (LePIDOPTERA: GELECHIIDAE)
}

\author{
Abdelkader harizia ${ }^{1}$, Abdelkader Benguerai ${ }^{1}$, Yahia Boukhari ${ }^{2}$ \\ ${ }^{1}$ Laboratory Research on Geo-Environment and Spaces Development, Faculty of Nature \\ and Life Sciences, University of Mascara, Algeria \\ ${ }^{2}$ Research Laboratory on Geomatics, Ecology and Environment, Faculty of Nature and \\ Life Sciences, University of Mascara, Algeria
}

(Received April 2019 - Accepted December 2019)

\begin{abstract}
Harizia, A. Benguerai, A. Boukhari, Y. 2019. Larvicidal activity of Bacillus thuringiensis kurstaki against Tuta absoluta (Lepidoptera: Gelechiidae). Lebanese Science Journal. 20(3): 352-362.

A commercial formulation of Bacillus thurengiensis var Kurstaki (BTK) (IAB Bt) has been shown to be effective in controlling Tuta absoluta Zeller larvae under laboratory conditions. Five concentrations are tested $((200, .350 ; 500 ; 650$ et 800 ppm) by ingestion, on the various larval stages (L1, L2, L3, L4 and L5). The larval mortality caused by BTK swelled with increasing concentrations. The high concentrations of 650 and 800 ppm give $100 \%$ mortality rates for the early stages L1, L2, L3 and L4. The acute toxicity (LC50) of BTK calculated for all larvae is 517 ppm. The lethal efficacy of BTK is noted 02 days, after the ingestion treatment, for the young stages (L1 and L2) and 04 at 6 days for the older larvae (L3 and L4) with a LT50, all larval stages combined equal to 2.6 days.
\end{abstract}

Keywords: BTK, Tuta absoluta, biological control, acute toxicity, LT50.

\section{INTRODUCTION}

The tomato leaf miner Tuta absoluta, native from South America (Siqueira et al., $2000)$, is a quarantine pest (EPPO, 2008) that has invaded all tomato growing regions in the world. The Mediterranean coasts are a favorable habitat for the multiplication of $T$. absoluta (Desneux et al., 2010), it was first reported in Spain in 2006 (Urbaneja, 2007) and then spread to other countries such as Morocco, Algeria, Tunisia and France (Guenaoui, 2008, Roditakis et al., 2010, Mohammed, 2010). Larval attack occurs over the entire aerial part of the plant (Filho et al., 2000) and can cause between $70 \%$ and

http://dx.doi.org/10.22453/LSJ-020.3.352-362 National Council for Scientific Research - Lebanon 2018®) lsj.cnrs.edu.lb/vol-20-no-3-2019/ 
$100 \%$ loss (Pratissoli and Parra, 2000). The use of intensive chemical applications , up to 36 sprays per season, yielded very variable results depending on the active ingredients while remaining ineffective for the complete eradication of the pest (Da Cunha et al., 2006 ; Luna et al., 2007). The misuse of certain active ingredients, such as abamectin and permethrin in Brazil, has led to the development of resistance in populations of $T$. absoluta and the destruction of useful auxiliary fauna (Siqueira et al . 2000 ; Siqueira et al ., 2001 ; Miranda et al, 2005). In addition, toxic residues in harvested fruits cause a serious human health problem (Medeiros et al., 2006; Pereira et al., 2008). With these multiple risks, many researchers have studied the alternatives as well as the effective combinations of means of fight against insect pests by using natural enemies (Filho et al., 2000 ; Marchiori et al., 2004 ; Salvo and Valladares, 2007), Entomopathogenic fungi (Shalaby et al., 2013, Harizia and Lazreg, 2016) plant extracts (Yankova et al., 2014, Bouchikhi et al., 2010, Bouchikhi-Tani el al., 2018) and bacteria (Youcef and Hassan, 2013, Noujeim et al., 2015). More than 250 biopesticides, representing $4.2 \%$ of the pesticide market, are sold worldwide, $80 \%$ of which are based on Bacillus thuringiensis (Bt) (Mark and Whalon, 2003; Ibrahim et al,. 2010). Most Bt insecticides contain deltaendotoxin crystals and spores that synergistically enhance the toxicity of crystals mainly against epidopteran, dipteran and coleopteran larvae. (Schnepf et al., 1998). Only 2 subspecies of Bt, kurstaki and aizawaï have been developed as an insecticide to control lepidopteran pests. The most common trade names for these products include Dipel $₫$ Dipel, Javelin ${ }^{\circledR}$, Thuricide ${ }^{\circledR}$, Worm Attack ${ }^{\circledR}$, Caterpillar Killer ${ }^{\circledR}$ et Bactospeine ${ }^{\circledR}$, but many small businesses sell similar products under various trade names (Sanchis and Bourguet, 2008).

Bt insecticides based on the Kurstaki or BTK subspecies, whose spectrum of action is limited to Lepidoptera, are widely used in the fight against forest defoliating caterpillars. (Martin, 2006; Roversi, 2008) especially in Algeria against the defoliating caterpillar corkoak Lymantria dispar L (Lepidoptera, Lymantriidae), the date moth Ectomyelois ceratoniae Zeller and the pine processionary Thaumetopea pytiocampa Schiff (Lepidoptera, Notodontidae) (Zammoum et al., 2013, Bouzar et al., 2014; Oumane et al., 2017). In order to be able to develop a strategy for the integrated protection of glass house tomato crops. This work aims to study, in the laboratory, the insecticidal efficacy of a commercial formulation of B. thuringiensis BTK (IAB-BT) on the different larval stages of T. absoluta.

\section{MATERIALS AND METHODS}

\section{Tuta absoluta}

Individuals of $T$. absoluta used in the experiments were reared on untreated greenhouse tomato plants (Lycopersicon esculentum Mill) in the experimental station of the Faculty of Naturel and Life Sciences, (University of Mascara). The greenhouse rearing was conducted in optimal conditions with a temperature of $25 \pm 2 \circ$ $\mathrm{C}$, a hygrometry of $70 \pm 10 \%$ and a photoperiod of $12 \mathrm{~h}$ : $12 \mathrm{~h}$. 


\section{Baccilus therungiensis var Kurstaki (BTK)}

The sample of $B$. thurengiensis var Kurstaki (tradename: IAB Bt), used in this study, is a microbiological insecticide which is available in the Algerian market. It is registered for the control of the pine and cedar caterpillar Thaumetopoea pityocampa (Denis \&Schiffermüller) (Lepidoptera: Notodontidae). The patchy bombyx Lymantria dispar L. and the date moth Ectomyelois ceratoniae Zeller. Bio insecticide is a wettable powder with a concentration of $32000 \mathrm{IU} \mathrm{g}^{-1}$.

\section{Larvicidal assay}

BTK larvicidal efficacy testing on $T$. absoluta involves the larvae being tested at concentrations of 200, 350, 500, 650 and $800 \mathrm{ppm}$ for ingestion toxicity. Larvae were individually placed in petri dishes $(6.5 \mathrm{~cm} \times 2.5 \mathrm{~cm})$ containing a Whatman filter paper moistened with distilled water and fed on fresh tomato leaves discs dipped in each of the five concentration. BTK treated leaves are used once, the larvae are then fed on untreated tomato leaves. Control larvae receive tomato leaves dipped in distilled water. The experiment was a randomized complete block design with replications consisting of 08 larvae per stage (L1, L2, L3, and L4) and concentration replicated three times. The experiment was carried out under controlled conditions in the laboratory at a temperature of $30^{\circ} \pm 0.5^{\circ} \mathrm{C}$, a relative humidity of $70 \pm 10 \%$ and a photo period of 14 hours. Larval mortality was checked every day for six days.

\section{Statistical analysis}

Data were analyzed by 1-way analysis of variance with ANOVA- test. The mortality rate of the larvae exposed to test was corrected using Abbott's formula (Abbotts, 1925):

$$
\text { Abott's formula: } \quad \mathrm{CM} \%=\frac{M 2-M 1}{100-M 1} \times 100
$$

With $\mathrm{CM} \%=\%$ corrected mortality. M2 $=\%$ mortality in treated larvae. $\mathrm{M} 1=$ mortality among controls.

Statistical significance of differences in mortality was examined by using the Chisquare test $\left(\chi^{2}\right)$. The level of significance was $\mathrm{P}<0.05$. The probit regression was used to calculate the lethal concentrations (LC50, LC90 and the median lethal time (LT50, including their confidence limits, at the various concentrations. The logistic regression model gives the LC50 and LT50 with their 95\% confidence intervals after the probit transformation of cumulative mortality rates. XLSTAT software was used for statistical analysis.

The LC50 and LT50 with their 95\% confidence intervals are given by the the logistic regression model after the probit transformation of cumulative mortality rates. XLSTAT software was used for statistical analysis. 


\section{RESULTS}

\section{Larvicidal efficacy}

The larval mortality of $T$. absoluta vary significantly among the $B$. thurengiensis var kurstaki treatments and increased with increasing concentrations $(\mathrm{F} 3.88=22.55, \mathrm{P}=$ 0.00008) (Table 1).

Table 1. Tuta absoluta larval corrected mortality (\%) after exposure to tomato leaflets treated with Bacillus thurengiensis var kurstaki at various concentration.

\begin{tabular}{|c|c|c|c|c|}
\hline Larvae & Concentration $(\mathbf{p p m})$ & 2 days & 4 days & 6 days \\
\hline & 200 & 0 & 0 & 0 \\
\hline $\mathbf{L 1}$ & 350 & 0 & 0 & 16.6 \\
\hline & 500 & 0 & 16,5 & 33 \\
\hline & 650 & 54,6 & 81,8 & 100 \\
\hline & 800 & 100 & 100 & 100 \\
\hline & 200 & 0 & 0 & 0 \\
\hline $\mathbf{L 2}$ & 350 & 0 & 0 & 0 \\
\hline & 500 & 36,44 & 76,11 & 83,89 \\
\hline & 650 & 77,77 & 100 & 100 \\
\hline & 800 & 100 & 100 & 100 \\
\hline & 200 & 0 & 0 & 0 \\
\hline $\mathbf{L 3}$ & 350 & 0 & 0 & 0 \\
\hline & 500 & 62,89 & 75,22 & 100 \\
\hline & 650 & 72,22 & 86,11 & 100 \\
\hline & 800 & 0 & 0 & 0 \\
\hline & 200 & 0 & 0 & 0 \\
\hline $\mathbf{L 4}$ & 350 & 0 & 10,71 & 20,59 \\
\hline & 500 & 66,43 & 77,62 & 100 \\
\hline & 650 & 47,02 & 73,45 & 100 \\
\hline
\end{tabular}

Three replicates per concentration and per larval stage. The results are significantly different at $\mathrm{P}<0.05$.

The lower concentration (200 ppm) had no effect on the different larval stages. 6 days after treatment, the concentration of $350 \mathrm{ppm}$ revealed a lower mortality rate of $16.6 \%$ for the L1 larvae but remained without lethal effect on the other stages. At $500 \mathrm{ppm}$, the results show mortality rates of 33\%,83, 89\%, 53, $55 \%$ and 20, 59 for L1, L2, L3 and L4 respectively. The ingestion treatment with the highest concentrations, 650 and $800 \mathrm{ppm}$, gives $100 \%$ mortality of all the larvae stages. The young larval stages (L1-L2) are more sensitive to BTK than the old stages (L3 - L4). All larval stages die within 2 to 6 days after ingestion treatment at concentrations of 650 and $800 \mathrm{ppm}$. The young stages L1 and 
L2 die after 2 days after exposure to the highest concentration of $800 \mathrm{ppm}$. While the total mortality of older larvae L3 and L4 occurs 6 days after treatment for concentrations 650 and $800 \mathrm{ppm}\left(\mathrm{F}_{3.056}=6.60 ; \mathrm{P}=0.003\right)$. The mortality of the control larvae did not exceed the rate of $5 \%$ throughout the duration of the experiment.

\section{Acute toxicity and median lethal time}

The estimated LC50 value shows that BTK is more toxic to young larval stages (L1 and L2) than the older ones. In fact, the results recorded in Table 2 show that the lowest value of the LC50 is obtained for L1 larvae with $409 \mathrm{ppm}$ and the highest for L4 with $554 \mathrm{ppm}$. The other intermediate stages L2 and L3 have respective estimated LC50 value of 449 and $516 \mathrm{ppm}$. The same trend is observed for CL90. The LC50 and the LC90 values and their confidence interval, for all larvae stages, are $517 \mathrm{ppm}(478-0.557)$ and $670 \mathrm{ppm}(621-748)$ respectively $\left(\mathrm{r}^{2}=0,783\right.$, chi $\left.^{2}=48.41, \mathrm{p}<0.0001\right)$ (Figure 1$)$. The respective lethal times TL50 and TL90 and their 95\% CI, calculated for all larval stages, are 2.601 days (2.454- 2.759) and 3,679 days $(3,415-4,046) \quad\left(r^{2}=0,761\right.$, $\mathrm{chi}^{2}=136.21, \mathrm{p}<0.0001$ ) (Figure 2).

Table 2. Estimates of Bacillus thurengiensis var kurstaki lethal concentration 50 and 90 (LC50 and LC 90) for Tuta absoluta, 6 days post treatment.

\begin{tabular}{|ccccc|}
\hline Larvae & LC50 (CL 95\%) & CL90 (CL 95\%) & $\mathbf{r}^{\mathbf{2}}$ & chi $^{\mathbf{2}}$ (Wald ) \\
\hline L1 & $409(371-438)$ & $471(442-513)$ & 0,887 & 25,38 \\
L2 & $449(419-475)$ & $533(505-576)$ & 0,864 & 36,99 \\
L3 & $516(479-549)$ & $654(614-714)$ & 0,744 & 47,54 \\
L4 & $554(517-585)$ & $671(634-729)$ & 0,769 & 36,83 \\
\hline
\end{tabular}

The low value of chi2 expresses a better fit to the linear regression model, and hence the reliability of the LC50. LC50 is considered valid when $\mathrm{p} \geq 0.05 \%$ (ddl= $1 ; \mathrm{p}<$ $0,0001)$. 


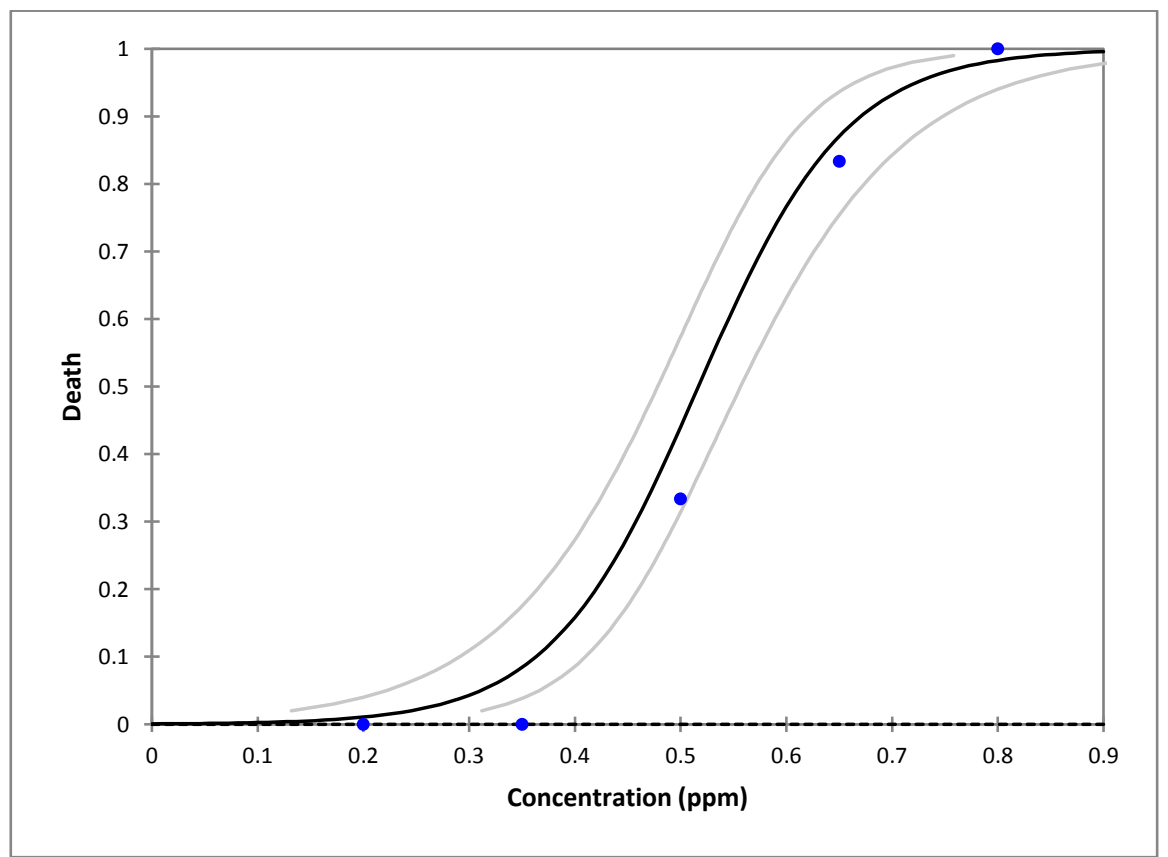

Figure 1. Probit model: dose-death dependence of Tuta absoluta treated with BTK at various concentration. Gray lines represent $95 \%$ confidence intervals.

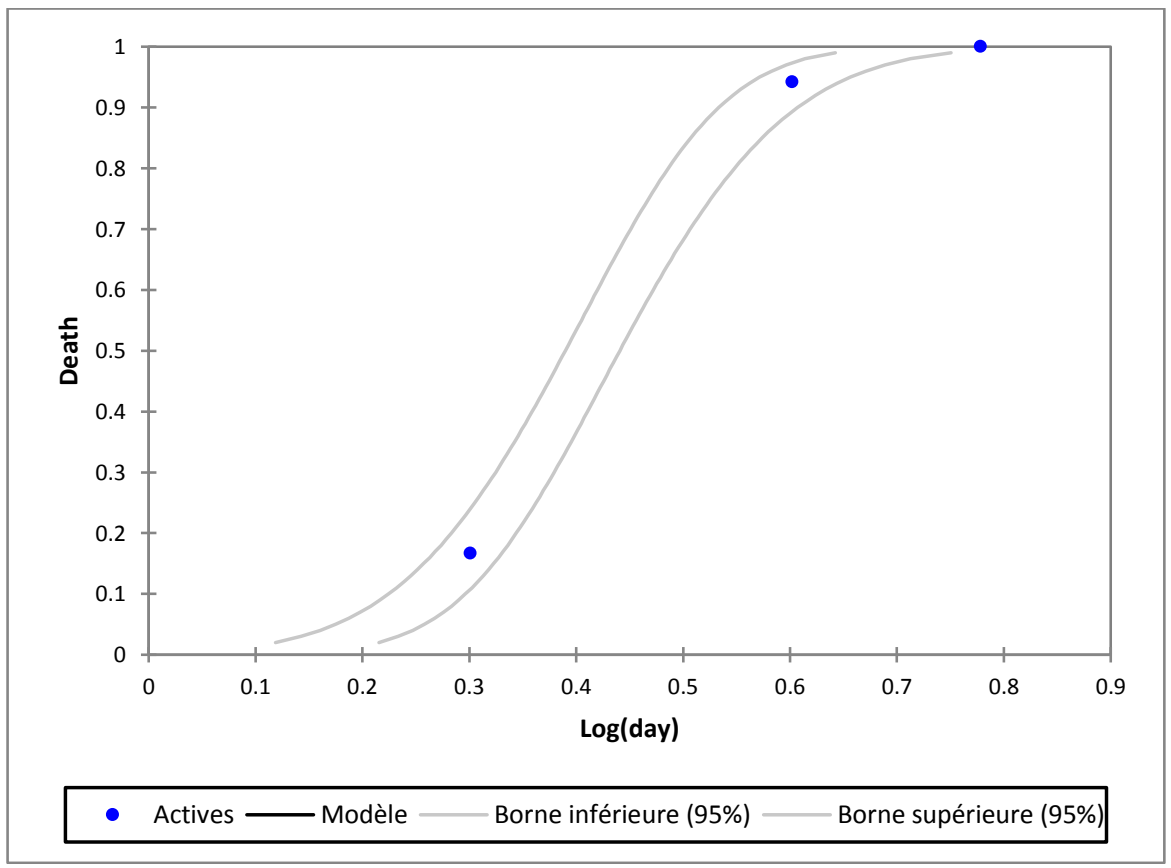

Figure 2. Probit model: day - death dependence of Tuta absoluta larval treated with BTK at various concentration. Gray lines represent $95 \%$ confidence intervals. 


\section{DISCUSSION}

The results obtained show that $B$. thurengiensis kurstaki has an insecticidal effect on the different larval stages of $T$. absoluta. The total mortality of the different larval stages of T. absoluta occurs after 6 days after the application of the highest concentrations of BTK ( 650 and $800 \mathrm{ppm}$ ). The biocidal potential of the commercial formulation of BTK in crops control is well known as a key element of integrated pest management programs (Roh et al., 2007). The results obtained in this study are in agreement with those obtained by Cabello et al. (2009), Gonzalez-Cabrera et al. (2011), Shalaby et al. (2013) et Alsaedi et al. (2017). These authors reported that $B$. thurengiensis kurstaki has sufficient efficacy against the four larval stages of tomato leaf miner. Aronson et al. (1986) specify that $B$. thurengiensis acts by ingestion, a few hours after the absorption of the product the caterpillar cannot feed itself because of the paralyze of the jaws then die a few days later. Our finding show that the larval mortality rate varies with the applied BTK concentrations and the age of the larvae. Indeed McGaughey (1985) states that the concentration to be applied depends on the size of the larva. A large larva requiring a higher concentration. In the present experiment, the young larval stages L1 and L2 are more sensitive and die after 02 days and 6 days for the old stages L3 and L4, treated at high concentrations (650 and 800ppm). In this regard, several authors emphasize on the excellent effectiveness of the bacterium in young stages of Lepidoptera. (Giustolin et al., 2001, Gonzalez-Cabera et al., 2011, Shalaby et al., 2013). Giustolin et al. (2001). In the same context, they point out that the speed of mortality of young stages compared to older stages is related to differences in feeding behavior. On the other side, Narmen and Hassan, (2013) reported that $53.5 \%$ to $100 \%$ mortality of larvae treated in the laboratory by the BTK die between 1 and 5 days. In general, Bt loses 50\% of its insecticidal potential within 1 to 3 days. However, some researchers report a longer residual activity (7 days, 10 days and 45 days) on tomato leaves (Theoduloz et al., 2003. Torres Gregorio et al., 2009). The toxic intensity of BTK with respect to lepidopteran pests is related to the strains and proportions of $\delta$-endotoxins contained in the different commercial formulations (Sanchis and lereclus, 1999).

Most Lepidoptera are sensitive to crystals produced by kurstaki strains (Aronson et al., 1986). During sporulation, BTK synthesizes crystal inclusions consisting essentially of one or more cytotoxic (Cry) and cytolytic (Cyt) cytotoxic proteins. These $\delta$-endotoxins are very specific to the target insect. They first require solubilization as well as toxin activation by the proteolytic enzymes of the insect (Jenkins et al., 2000). Then they bind specifically to membrane receptors located in the intestinal cells. Finally, this toxin becomes oligomerized. It forms a membrane pore, inducing intestinal paralysis and the death of the insect (Höfte \& Whiteley, 1989; Mark \& Whalon , 2003; Bravo et $a l ., 2007)$. For most Lepidoptera, protein crystals are solubilized by the alkaline $\mathrm{pH}$ (1011) of the insect's gut (Hofmann et al., 1988).

The results obtained, in this work, show that the formulation of B. thurengiensis var kurstaki has a high insecticidal efficacy on all larval stages of $T$. absoluta and in particular on the young stages. BTK could be a key element in developing a rational 
strategy for controlling tomato leaf miner. Further research will have to be undertaken in the area of combining BTK with other means of control.

\section{REFERENCES}

Abbott, W. S. 1925. A method of computing the effectiveness of an insecticides. Journal of Economic Entomology, 18: 265-267

Alsaedi, G. Ashouri, A. Talaei-Hassanloui, R. 2017. Evaluation of Bacillus thuringiensis to Control Tuta absoluta (Meyrick) (Lepidoptera: Gelechiidae) under Laboratory Conditions. Agricultural Sciences, 8: 591-599.

Aronson, A. I. Beckman, W. et Dunn, P. 1986. Bacillus thuringiensis and Related Insect Pathogens. Microbiological Reviews, 50(1): 1-24.

Bouchikhi-Tani, Z. Khelil, A. M. Bendahou, M. 2018. Evaluation des propriétés larvicides des huiles essentielles extraites de cinq plantes aromatiques d'Algérie: essai sur la mite Tineola bisselliella (Lepidoptera: Tneidae). Lebanese Science Journal, 19(2): 187-199.

Bouchikhi-Tani, Z. Bendahou, M. Khelil, M. A. 2010. Lutte contre le bruche Acanthoscelides obtectus et la mite Tineola bisselliella par les huiles essentielles extraites de deux plantes aromatiques d'Algérie. Lebanese Science Journal, 11(1): 55-68.

Bouzard, E. K. Allal-Benfekih, L. Djazouli, Z. E. 2014. Effets comparés des traitements biologiques seuls ou combinés sur les teneurs en réserves énergétiques des chenilles de la processionnaire du pin Thaumetopea pytiocampa schiff (Lepidoptera, Notodontidae). Revue Agrobiologia, 6: 47-52.

Bravo, A. Gill, S. S. et Soberon, M. 2007. Mode of action of Bacillus thuringiensis Cry and Cyt toxins and their potential for insect control. Toxicon, 49: 423-435.

Cabello, T. Gallego, J. R. Fernandez, F. J. Soler, A. Beltran, D. Parra, A. Vila, E. 2009. The damsel bug Nabis pseudoferus (Hem.:Nabidae) as a new biological control agent of the South American Tomato Pinkworm, Tuta absoluta (Lep.: Gelechiidae), in tomato crops of Spain. OIBC/WPRS Bull, 49: 219-223.

Da Cunha, U. S. Vendramim, J. D. Rocha, W. C. Vieira, P. C. 2006. Fractions of Trichilia pallens with insecticidal activity against Tuta absoluta. Pesquisa Agropecuária Brasileira, 41: 1579-1585.

Desneux, N. Wajnberg, E. Wyckhuys, K. A. G. Burgio, G. Arpaia, S. Narvaez-Vasquez, C. A. Gonzalez- Cabrera, J. Ruescas, D. C. Tabone, E. Frandon, J. Pizzol J. Poncet, C. Cabello, T. et Urbaneja, A. 2010. Biological invasion of European tomato crops by Tuta absoluta: ecology, geographic expansion and prospects for biological control. Journal of Pest Science, 83: 197-21.

Filho, M. Vilela, E. Attygalle , A. Meinwald, J. Svatos, A. et Jham, G. 2000. Field trapping of tomato moth, Tuta absoluta, with pheromone traps. Journal of Chemical Ecology, 26(4): 875-881.

Giustolin, TA. Vendramim, J. D. Alves, S. B. Vieira, S. A. et Pereira, R. M. 2001. Susceptibility of Tuta absoluta (Meyrick) (Lep., Gelechiidae) reared on two species of Lycopersicon to Bacillus thuringiensis var. kurstaki. Journal of Applied Entomology, 125: 551-556. 
Gonzalez-Cabrera, J. Molla, O. Monton, H. et Urbaneja, A. 2011. Efficacy of Bacillus thuringiensis Berliner in controlling the tomato borer, Tuta absoluta Meyrick (Lepidoptera: Gelechiidae). BioControl, 56: 71-80.

Guenaoui, Y. 2008. Nouveau ravageur de la tomate en Algérie : Première observation de Tuta absoluta, mineuse de la tomate invasive, dans la région de Mostaganem, au printemps 2008. Phytoma, 617: 18-19.

Harizia A. and Lazreg, F. 2016. Efficacy of Paecilomyces fumosoroseus isolate p83 (Ascomycota: Hypocreales) against Dociostaurus maroccanus. Biopesticides international, 1: 1-7.

Hofmann, C. Luthy, P. Hutter, R. et Pliska, V. 1988. Binding of the $\delta$ endotoxin from Bacillus thuringiensis to brush- border membrane vesicles of the cabbage butterfly (Pieris brassicae). European Journal of Biochemistry, 173: 85-91.

Höfte, H. et Whiteley, H. R.1989. Insecticidal crystal proteins of Bacillus thuringiensis. Microbiological Reviews, 53(2): 242-255.

Jenkins, J. L. Lee, M. K. Valaitis, A. P. Curtiss, A., et Dean, D. H. 2000. Bivalent sequential binding model of a Bacillus thuringiensis toxin to Gypsy moth aminopeptidase N Receptor. Journal of Biological Chemistry, 275: 14423-14431.

Luna, M. G. Sanchez, N. Pereyra, P. C. 2007. Parasitism of Tuta absoluta (Lepidoptera, Gelechiidae) by Pseudapanteles dignus (Hymenoptera,Braconidae) under laboratory conditions. Environmental Entomology, 36: 887-893.

Marchiori, C. H. Silva, C. G. et Lobo, A. P. 2004. Parasitoids of Tuta absoluta (Meyrick, 1917) (Lepidoptera: Gelechiidae) collected on tomato plants in Lavras, state of Minas Gerais, Brazil. Brazilian Journal of Biology, 64: 551-552.

Mark, E. et Whalon B. A. W. 2003. Bt: Mode of action and use. Archives of Insect Biochemistry and Physiology, 54:200-211.

Martin J. C. 2006. Bacillus thuringiensis, 30 ans de lutte contre les chenilles défoliatrices en forêt. Phytoma, 590: 4-7.

Medeiros, M.A. de Vilela, N. J. et Franca, F. H. 2006. Eficiência técnica e econômica do controle biológico da traça-do-tomateiro em ambiente protegido. Horticultura Brasileira, 24(2): 180-184.

Mc Gaughey, W. H. 1985. Insect resistance to the biological insecticide Bacillus thuringiensis. Science, 229:193-195.

Miranda, M. M. M. Picanco, M. C. Zanuncio, J. C. Bacci, L. da Silva, E. M. 2005. Impact of integrated pest management on the population of leafminers, fruit borers, and natural enemies in tomato. Ciencia Rural, 35: 204-208.

Mohammed, A.S. 2010. New record for leafminer, Tuta absoluta (Lepidoptera: Gelechiidae) infested tomato plantations in Kafer El-Sheikh region. Journal of Agricultural Research, 36(2): 238-239.

Noujeim, E. Sakr, J. El Sayegh, D. and Nemer. N. 2015. In vitro susceptibility of the pea leafminer Liriomyza huidobrensis pupae to entomopathogenic Heterorhabditis indica and Beauveria bassiana. Lebanese Science Journal, 16(2): 19- 26.

OEPP. Organisation Européenne et Méditerranéenne pour la Protection des Plantes.2008. Fiches informatives sur les organismes de quarantaine. Bulletin OEPP/EPPO, 35: 434-449. 
Ouamane, A. T. Bensalah, M. K. et Djazouli, Z.E. 2017. Approche au monitoring de la pyrale des dattes Ectomyelois ceratoniae Zeller par le recours aux moyens biologiques. Revue Agrobiologia, 7(1): 312-320.

Pereira, G. V. N. Maluf, W. R. Goncalves, L. D. do Nascimento, D. R., Gomes, L. A. A., Licursi, V. 2008. Selection towards high acylsugar levels in tomato genotypes and its relationship with resistance to spider mite (Tetranychus evansi) and to the South American pinworm (Tuta absoluta). Ciencia e Agrotecnologia, 32: 9961004.

Pratissoli, D. et Parra J. R. P. 2000. Fertility life table of Trichogramma pretiosum (Hym., Trichogrammatidae) in eggs of Tuta absoluta and Phthorimaea operculella (Lep., Gelechiidae) at different temperatures. Journal of Applied Entomology, 124: 339342.

Roditakis, E. Papachristos, D. et Roditakis, N. E. 2010. Current status of the tomato leafminer Tuta absoluta in Greece. Bulletin OEPP/EPPO, 40(2): 163-166.

Roh, J. Y. Jae, Y. C. Ming, S. L. Byung, R. J. Yeon, H.E. 2007. Bacillus thuringiensis as a specific, safe, and effective tool for insect pest control. Journal of Microbiology and Biotechnology, 17(4): 547-559.

Roversi P. F. 2008. Aerial spraying of Bacillus thuringiensis var. kurstaki for the control of Thaumetopoea processionea in Turkey oak woods. Phytoparasitica, 36(2): 175-186.

Sanchis, V. and Lereclus, D. 1999. Bacillus thuringiensis: a biotechnology model. Journal de la Société de Biologie, 193(6): 523-30.

Sanchis,V. Bourguet, D. 2008. Bacillus thuringiensis: applications in agriculture and insect resistance management. A review. Agronomy for Sustainable Development, 28(1): 11-20.

Salvo, A. et Valladares, G. R. 2007. Leafminer parasitoids and pest management. Ciencia e Investigacion Agraria, 34(3): 125-142.

Schnepf, E. Crickmore, Van Rie, J. Lereclus D. Baum J. Feitelson J. Zeigler D. R. et Dean D. H. 1998 . Bacillus thuringiensis and Its Pesticidal Crystal Proteins. Microbiology and Molecular Biology Reviews, 62: 3775-806.

Shalaby, H. H. Faragalla, F. H. El-Saadany, H. M. et Ibrahim, A. A. 2013. Efficacy of three entomopathogenic agents for control the tomato borer, Tuta absoluta (Meyrick) (Lepidoptera: Gelechiidae). Nature and Science, 11(7): 63-72.

Siqueira, H. A. Guedes R. N. Fragoso D. B. et Magalhães L. C. 2001. Abamectin resistance and synergism in brazilian populations of Tuta absoluta (Meyrick) (Lepidoptera: Gelechiidae). International Journal Pest Management, 47: 247251.

Siqueira, H. A. Guedes, R. N. C. et Picanco, M. C. 2000. Insecticide resistance in populations of Tuta absoluta. Agricultural and Forest Entomology, 2: 147-153.

Theoduloz, C. Vega, A. Salazar, M. Gonzalez, E. Meza-Basso, L. 2003. Expression of a Bacillus thuringiensis d-endotoxin cry1Ab gene in Bacillus subtilis and Bacillus licheniformis strains that naturally colonize the phylloplane of tomato plants (Lycopersicon esculentum, Mills). Journal of Applied Microbiology, 94: 375381. 
Torres Gregorio, J. Argente, J. Diaz M. A. Yuste, A. 2009. Applicacion de Beauveria bassiana en la lucha biologica contra Tuta absoluta. Agrıcola Vergel: Fruticultura, Horticultura, Floricultura, 326: 129-132.

Urbaneja, A. Vercher, R. Navarro, V. Garcia, M. F. Porcuna, J. L. 2007.La polilla del tomate, Tuta absoluta. Phytoma españa, 194: 16-23.

Yankova, V. Valchev, N. et D. Markova. 2014. Effectiveness of phytopesticide Neem Azal T/S $®$ against tomato leaf miner (Tuta absoluta Meyrick) in greenhouse tomato. Bulgarian Journal of Agricultural Science, 20: 1116-1118.

Youcef, N. A. and Hassan, G. M. 2013. Bioinsecticide activity of Bacillus thuringiensis isolates on tomato borer, Tuta absoluta (Meyrick) and their molecular identification. African Journal of Biotechnology, 12(23) : 3699-3709.

Zamoum, M. Khemici, M. et Bahmane, R. 2013. Gradation et régulation de Lymantria dispar L. (Lepidoptera, Lymantriidae) avec Bacillus thuringiensis Berliner var. kurstaki dans les subéraies du centre et de l'est algérien. Phytoprotection, 94: 1318. 